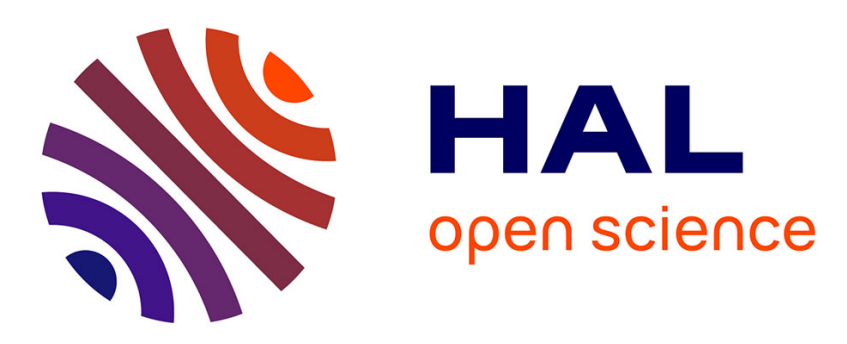

\title{
Nested variation of soil arthropod communities in isolated patches of vegetation on a rocky outcrop
}

Charlotte Kounda-Kiki, Léonide Célini, Jean-François Ponge, Philippe Mora, Corinne Sarthou

\section{- To cite this version:}

Charlotte Kounda-Kiki, Léonide Célini, Jean-François Ponge, Philippe Mora, Corinne Sarthou. Nested variation of soil arthropod communities in isolated patches of vegetation on a rocky outcrop. Soil Biology and Biochemistry, 2009, 41 (2), pp.323-329. 10.1016/j.soilbio.2008.11.008 . hal-00494634

\section{HAL Id: hal-00494634 \\ https://hal.science/hal-00494634}

Submitted on 23 Jun 2010

HAL is a multi-disciplinary open access archive for the deposit and dissemination of scientific research documents, whether they are published or not. The documents may come from teaching and research institutions in France or abroad, or from public or private research centers.
L'archive ouverte pluridisciplinaire $\mathbf{H A L}$, est destinée au dépôt et à la diffusion de documents scientifiques de niveau recherche, publiés ou non, émanant des établissements d'enseignement et de recherche français ou étrangers, des laboratoires publics ou privés. 
1 Type of contribution: Regular paper

2

3 Date of preparation: 22 September 2008

4

5 Title: Nested variation of soil arthropod communities in isolated patches of vegetation on a

6 rocky outcrop

7

8 Names of authors: C. Kounda-Kiki, L. Celini, J.F. Ponge*, P. Mora, C. Sarthou

9

10 Complete postal addresses or affiliations:

11

12 C. Kounda-Kiki, J.F. Ponge, C. Sarthou: Muséum National d'Histoire Naturelle, CNRS UMR

137179,4 avenue du Petit-Château, 91800 Brunoy, France

14

15

L. Celini, P. Mora: Université Paris 12, UMR 137 BioSol, Laboratoire d'Écologie des Sols

16 Tropicaux, 61 avenue Henri-Varagnat, 94010 Créteil Cedex, France

17

18 Full telephone, Fax number and E-mail address of the corresponding author:

19

20 Tel. +33160479213

$21 \quad$ Fax +33160465009

22 E-mail: ponge@mnhn.fr

\footnotetext{
* Complete correspondence address to which the proofs should be sent: Jean-François Ponge, Muséum National d'Histoire Naturelle, CNRS UMR 7179, 4 avenue du Petit-Château, 91800 Brunoy, France
} 


\section{Abstract}

The combined effects of isolation within an unfavourable matrix and vegetation development were studied in patches of scrub vegetation on a tropical inselberg (Nouragues, French Guiana). Three thickets $\sim 10 \mathrm{~m}^{2}$ area were sampled, located at $\sim 30 \mathrm{~m}$ distance from each other, in which the same vegetation types were present at less than $3 \mathrm{~m}$ distance: canopies of Clusia minor (Clusiaceae) and Myrcia saxatilis (Myrtaceae), two stages of thicket development, and zones of destruction by fire. The shallow organic soil was sampled over $\sim 2$ $\mathrm{dm}^{2}$ and down to $10 \mathrm{~cm}$. The matrix was comprised of granite without any soil development. Arthropods were classified into morphospecies and their food diets were characterized by optical methods. The effect of isolation (between-thicket variation) on morphospecies composition was negligible, while that of vegetation type and fire (within-thicket variation) was prominent, as ascertained by principal component analysis and tested by partial redundance analysis. The importance of keystone structures (stages of vegetation development) was stressed, and interpreted to the light of taxonomic and foodweb knowledge.

Keywords: arthropod communities, tropical inselbergs, keystone structures, isolation, vegetation types, food diets

\section{Introduction}

The joint development of soil and vegetation exerts a profound influence on the composition of soil animal communities (Parr, 1978). Trends in the abundance and diversity of arthropod assemblages have been observed in primary as well as secondary successions, and were interpreted as a response to changes in the amount and diversity of habitats and 
resources (Shure and Ragsdale, 1977; Scheu and Schulz, 1996; Paquin and Coderre, 1997). In fragmented landscapes, fragments may differ from each other due to dispersal limits for wingless arthropods (Hopkins and Webb, 1984; De Vries and Den Boer, 1990; but see Rantalainen et al., 2004). Dispersal barriers may impede soil invertebrates to colonize newly created favourable habitats, thereby putting limits to the seral (successional) development of their communities (Weigmann, 1982; Ojala and Huhta, 2001; Ponge et al., 2006). 55

Rocky outcrops, known in tropical rain forests under the name of inselbergs (Bremer and Sander, 2000) are good models for studying the combined influence of isolation and vegetation development. Habitats favourable to soil invertebrates are patches of vegetation isolated within an unfavourable environment (matrix) made of granite covered with a thin cyanobacterial biofilm (Sarthou et al., 1995; Sarthou and Villiers, 1998; Büdel et al., 2002). In the absence of a continuous plant cover, soil is confined to vegetation clumps and rock pools where organic matter (plant litter) or sand particles (granitic arena) accumulate, respectively (Sarthou and Grimaldi, 1992; Porembski et al., 2000; Sarthou, 2001). Local disturbances, such as lighning, create small gaps within shrub thickets and are the origin of micro-scale successional processes which contribute to the renewal of the plant community (Ibisch et al., 1995; Kounda-Kiki et al., 2008).

In a previous study on the Nouragues inselberg (French Guiana, South America) we showed that soil arthropod communities differed between vegetation patches at varying stages of development (Kounda-Kiki et al., 2004), but the influence of isolation has so far been neglected. We expect that patches of invertebrate fauna will differ in their composition due to the simultaneous influence of isolation and vegetation type. The question is which of these factors prevails. We suggest that the vegetation type (including fire effects) is prevailing as it 
74 dictates assembly rules, through (i) cascade effects within soil foodwebs (Hansen, 2000;

75 Wardle et al., 2004; Hedlund et al., 2004), and (ii) habitat cues to soil invertebrates (Evans, 1983; Salmon and Ponge, 2001; Coulson et al., 2003). For testing this hypothesis we selected patches of shrub vegetation of similar area which were (i) isolated by vegetation-free granitic terrain, (ii) were at the same stage of thicket development, (iii) showed distinct signs of within-patch successional development. The influence of vegetation type and fire (withinpatch variation) will be compared to that of isolation (between-patch variation).

\section{Material and methods}

\subsection{Study sites}

85

The Nouragues inselberg $\left(4^{\circ} 3^{\prime} \mathrm{N}, 52^{\circ} 42^{\prime} \mathrm{W}\right.$, alt. $\left.410 \mathrm{~m}\right)$ is located in French Guiana (South America), $100 \mathrm{~km}$ south of the Atlantic Coast, in the Nouragues Biological Reserve. It is dome-shaped, of the so-called whaleback type (Bremer and Sander, 2000). Geomorphological features of the Precambrian granitic substrate include flat surfaces, steep slopes, depressions and gullies, with smooth pellicular erosion (exfoliation) due to high thermic contrasts and chemical dissolution of plagioclases and potassic feldspars (Sarthou and Grimaldi, 1992). Mean annual precipitation reaches 3250 mm, with a dry season from August to November and a wet season from December to July, interrupted by a very short dry season in March (Sarthou and Villiers, 1998). The air temperature varies daily from 18 to $55^{\circ} \mathrm{C}$ and the air moisture varies from 20 to $100 \%$ (Sarthou, unpublished $\mathrm{PhD}$ thesis). The temperature of the bare rock may reach $75^{\circ} \mathrm{C}$ in the dry season. Most of the surface is covered by cyanobacteria (Sarthou et al., 1995), which take part in mineral weathering and fix carbon and nitrogen (Sarthou and Grimaldi, 1992). 
99

100

101

102

103

104

105

106

107

108

109

110

111

112

113

114

115

116

117

118

Vascular vegetation, locally called 'rock savanna' (English translation of 'savaneroche'), is made of scattered patches of herb and shrub communities (Fig. 1), but steep slopes are covered only with cryptogamic vegetation. Organic soils $(10-50 \mathrm{~cm}$ depth), acidic (pH 4.0-5.5), with a high faunal and microbial activity, are formed under patches of woody vegetation where humified organic matter is prevented from flushing by a dense root network (Sarthou and Grimaldi, 1992; Kounda-Kiki et al., 2006). The joint development of soil and vegetation has been studied by Sarthou and Grimaldi (1992), Vaçulik et al. (2004), KoundaKiki et al. (2006) and Sarthou et al. (2009). Two successional stages were determined within shrub thickets, Clusia minor only (an epilithic Clusiaceae able to establish within bromeliacean mats) as an earlier stage then a mixture of C. minor and several Myrtaceae such as Myrcia saxatilis. The analytical study of humus profiles led to the conclusion that fire, followed by fungal and termite activity, exerted a prominent role in the passage from the Clusia stage to the Clusia-Myrcia stage (Kounda-Kiki et al., 2008; Sarthou et al., 2009).

\subsection{Sampling and extraction of arthropods}

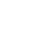

$\mathrm{m}^{2}$ ) on the lower terrace called 'Les Terrasses', south-west of a cliff, on slopes averaging $20 \%$. They were located approximately at a distance of $\sim 30 \mathrm{~m}$ from each other, forming a triangle. They were separated by an undulating surface of granite without any vegetation clumps inbetween. Inside each shrub thicket we selected three areas, each representing a stage of the internal cyclic succession (Sarthou et al., 2009), (i) Clusia (Clu), a zone under the canopy of $C$. minor only, (ii) a zone of destruction (Zd), with branch litter and accumulated humus but without any woody canopy nor leaf litter, (iii) Myrcia (Myr), a zone under the 
124 canopy of $M$. saxatilis. Samples taken within the same thicket were not at more than $3 \mathrm{~m}$

125 distance from each other.

126

127

128

129

130

At the centre of each plot litter and soil were collected by forcing down an stainless steel cylindrical frame with cutting edge $\left(15 \mathrm{~cm}\right.$ diameter, $10 \mathrm{~cm}$ height, $\left.1.8 \mathrm{dm}^{3}\right)$. Care was taken that litter, when present, was kept intact. Litter/humus samples were immediately put in plastic bags then transported to the laboratory within three days. Extraction of arthropods started immediately after arrival, by putting the samples into Berlese funnels $(5 \mathrm{~mm}$ mesh size, $15 \mathrm{~W}$ bulb lights). Duration of extraction was 10 days, after checking for the absence of last-minute fall of specimens. In order to keep enough free space around drying litter and humus, each sample was halved then extracted in two distinct funnels. Specimens were collected and preserved in $95 \%(\mathrm{v} / \mathrm{v})$ ethyl alcohol until identification. In the absence of taxonomic knowledge on most Guianan arthropods we classified specimens on the basis of morphological characters which were visible at 40x magnification, i.e. we identified morphospecies sensu Oliver and Beattie (1996). Morphospecies were further classified at a supra-species level, mostly order.

The size of each morphospecies was measured to the nearest $10 \mu \mathrm{m}$ by examining bigger specimens with a micrometer in the eye piece of a dissecting microscope. Several specimens of each morphospecies (10 when possible, less in other cases) were mounted in chloral-lactophenol, and their gut contents were observed by transparency of after dissection. Sizes of arthropods were classified in three classes: Size Class $1(<0.4 \mathrm{~mm})$, Size Class $2(0.4-$ $1 \mathrm{~mm})$ and Size Class $3(>1 \mathrm{~mm})$. Gut contents were classified into 9 categories and their contribution to the mean diet of the morphospecies was visually estimated to the nearest $5 \%$. 
148 Empty guts mean that the animals either had not ingested anything at the time of extraction or

149 had a fluid food diet (sap, blood or prey externally digested).

150

\subsection{Data analysis}

152

The distribution of morphospecies was analysed by Principal Components Analysis

154 (Legendre and Legendre, 1998). Morphospecies were projected in a distance bi-plot diagram,

155 together with thickets (A, B, C) and vegetation types ( $\mathrm{Zd}, \mathrm{Clu}, \mathrm{Myr}$ ) as supplementary

156 (explanatory) variables. Other bi-plots were used to show the projection of community

157 descriptors (number of morphospecies, number of individuals, size classes, food items,

158 taxonomic groups), which were added as supplementary variables (calculated as \%

159 individuals or morphospecies in each sample). Partial redundancy analysis, followed by

160 Monte-Carlo procedure, was used to test alternatively for residual effects of isolation (thicket)

161 or successional stage (vegetation type) after controlling for the other factor (Legendre and

162 Legendre, 1998). All these calculations were performed using XLSTAT $^{\circledR}$ version 2008.2.01

163 (Addinsoft $^{\circledR}$ software company).

164

Total species richness was estimated by functional extrapolation using the asymptotic

166 Michaelis-Menten function (Colwell and Coddington, 1994). The Jaccard index of similarity

167 was calculated between all pairs of samples. Calculations were performed using the free

168 software application EstimateS version 8.0 (http://purl.oclc.org/estimates).

\section{Results}


The Michaelis-Menten estimator for species richness, computed for the Mao Tau

173 species accumulation curve, was 263.5 , thus our samples covered $\sim 78 \%$ of the predicted total

174

175

176

177

178

179

180

181

182

183

184

185

186

187

188

189

190

191

192

193

194

195

196 species richness. Most specimens were mites (Acarida), encompassing 124 (60\%) out of a total of 205 morphospecies and $3472(51 \%)$ out of a total of 6845 individuals. Collembola were the second most abundant group in individuals (42\%) but they represented only $7 \%$ of the total number of morphospecies. There was an important pool of arthropods (35 to $60 \%$ of morphospecies, 75 to $94 \%$ of individuals) common to all three vegetation types (Table 1) and all three thickets (Table 2). They form the basic component of the inselberg arthropod community, seemingly unaffected by either isolation or within-thicket vegetation dynamics. It can be observed that the pool of species common to Clu and Myr was more important than that common to either $\mathrm{Zd}$ and $\mathrm{Clu}$ or $\mathrm{Zd}$ and Myr (Table 1). The number of morphospecies increased in the order $\mathrm{Zd}<\mathrm{Myr}<\mathrm{Clu}$, while the number of individuals increased in the order Myr $<\mathrm{Clu}<\mathrm{Zd}$.

\section{(1)}

86

Factor 1 of PCA (eigen value 35.7, 17.6\% of total inertia) separated species associated with destruction zones (Zd) from those associated with either Clusia (Clu) or Myrcia (Myr) stages, while Factor 2 (eigen value 34.1, 16.9\% of total intertia) separated Clu from Myr. The three vegetation types $(\mathrm{Zd}, \mathrm{Clu}, \mathrm{Myr})$ were projected far from the origin, while the three thickets $(\mathrm{A}, \mathrm{B}, \mathrm{C})$ were projected near the origin, thereby indicating that species composition (as depicted by the two components with highest eigen values) was better explained by within-thicket than by between-thicket variation (Fig. 2). This was verified by partial RDA followed by Monte-Carlo permutation tests (500 permutations). When between-thicket variation (isolation) was eliminated, within-ticket variation (vegetation type, successional stage) explained a significant part of the residual variation $(\mathrm{P}<0.05)$, while isolation did not explain any residual variation when the effect of vegetation type was discarded $(P=0.29)$. 
The bi-plot projection of community descriptors (Fig. 2) showed that Factor 1 opposed morphospecies to individuals, depicting an opposite trend between $\mathrm{Zd}$ (many individuals but few species) to Clu and Myr (more species but fewer individuals). The numerical abundance of fauna in $\mathrm{Zd}$ was mainly due to microarthropods, i.e. mites (Acarida) and springtails

202 (Collembola). All taxonomic groups except Acarida and Collembola exhibited positive values 203 for Factor 1, both when counted as morphospecies and individuals. Acarida and Collembola were more abundant in $\mathrm{Zd}$ (negative values for individuals) but more diversified in the other two environments (positive values for morphospecies). The mean size of arthropods increased with Factor 1, which was mainly due to an opposition between Size Class $1(<0.4 \mathrm{~mm})$ and Size Class 2 (0.4-1 mm).

The bi-plot projection of food diets contributed by both individuals and morphospecies (Fig. 3) showed that morphospecies feeding on bacterial and those with empty guts were mainly found in $\mathrm{Zd}$ while those feeding on plant material were mainly found in Clu and Myr. At the individual level, similar results were depicted, except that, in addition to discrepancies mentioned above, more individuals consumed fungal spores and humified organic matter in Zd.

Factor 2 of PCA opposed arthropod morphospecies living in Clu and Myr. There were more morphospecies in Clu than in Myr (Table 1). Diptera, Crustacea and Pseudoscorpionida were abundant in Myr, both as morphospecies and individuals, while Acarida exhibited a high number of morphospecies (but not of individuals, which were higher in $\mathrm{Zd}$ ) in Clu (Fig. 2). Size classes differed also between Clu and Myr, with biggest arthropods (Size Class 3, >1 $\mathrm{mm}$ ) associated with Myr. Concerning food diets, pollen and fungal hyphae were associated 
with Clu, while individuals with empty guts, and morphospecies with animal prey (both typical of predatory behaviour) were associated with Myr (Fig. 3).

\section{Discussion}

\subsection{The combined effects of isolation and vegetation type on arthropod communities}

Despite a low level of replication (3 thickets, 3 vegetation types in each), sampling allowed to record $78 \%$ of the predicted total species richness. This can be explained by a high degree of similarity among samples (mean Jaccard index $0.33 \pm 0.06$ mean \pm SD). Despite the presence of a pool of species common to all thickets and all vegetation types, we showed that the internal cycle of change within shrub thickets of the rock savanna controlled the composition of arthropod communities both at the taxonomic and at the foodweb level and that the effect of isolation was negligible compared to that of short-distance vegetation change. Although distance separating thickets $(30 \mathrm{~m})$ was at least ten times that separating samples inside a thicket $(\leq 3 \mathrm{~m})$, communities living in separate thickets differed less than those living under different vegetation types within the same thicket. Can we apply to soil animal communities the famous microbiologist's tenet that 'everything is everywhere, but, the environment select' (De Wit and Bouvier, 2006) or is there another plausible explanation? We can rule out that Clusia thickets were not isolated at all and that emigration and immigration could take place in the absence of dispersal or ecological barriers. A thorough examination of the granite substrate, either covered by cyanobacterial biofilms or not, did not reveal any surface movement of animals, except termites (not found in our samples) and some trombidids (only 4, belonging to the same morphospecies, among 6845 specimens found in our samples). However, it should be considered that during the rainy season the granite 
247

surface was regularly flushed down with precipitation water thus possibly transporting invertebrates and their propagules (eggs, cocoons, pupae). This might explain passive dispersal along gullies but not the existence of a widespread common population. Note that, if dispersal of arthropods was effective on the inselberg, this cannot explain how nearby communities might differ more than remote ones.

Further studies embracing a wide array of distances and topographical relationships are awaited in order to measure the exchanges of species and of genotypes within species which may occur between vegetation clumps. To the present state of our knowledge, we cannot say whether vegetation clumps are issued from the fragmentation of a forest ecosystem or from the colonization of vegetation 'islands'. However, the most plausible explanation for the presence of a widespread pool of species in an otherwise harsh environment is that present-day shrub thickets are remnants of a more complete cover by woody vegetation and their associated organic soils.

Changes in soil arthropod communities are known to occur, in response to changes in vegetation composition (Decaëns et al., 1998; David et al., 1999; Vohland and Schroth, 1999), age of trees (Baguette and Gérard, 1993; Loranger et al., 2001), amount of litter (Gill, 1969; Garay and Hafidi, 1990; David et al., 1991), soil/humus type (Van der Drift, 1962; Chagnon et al., 2000; Loranger-Merciris et al., 2007), micro-climate changes (Majer, 1984; Shure and Phillips, 1991) or these factors combined (Barclay-Estrup, 1974; Scheu and Schulz, 1996; Salmon et al., 2006). Considering the environment at the scale of a soil arthropod, each shrub thicket of the rock savanna should be considered as a landscape in itself (Chust et al., 2003), into which invertebrate communities are spatially organized in patches according to small-scale environmental heterogeneity (Hamilton and Sillman, 1989; Torgersen et al., 1995; 
272 Cannavacciuolo et al., 1998). Movements of animals within such landscapes will allow them

273 to select places favourable for foraging and reproduction and, of paramount importance in

274 harsh environments, refuges during unfavourable periods (Fairhurst, 1969; Joosse, 1981;

275 Huhta, 1996), thus without any depressive effect of habitat loss (Stanton and Tepedino, 1977;

276 Fahrig, 2003; Matlack and Leu, 2007). Competition and assembly rule mechanics (Drake,

277 1990) would reduce species richness at a much finer scale than that of the thicket, thus

278 without any strong and durable effect on the community as a whole (Ricklefs, 1987;

279 Bengtsson, 2002). The nested arrangement of scales of variation in the rock savanna of the

280 Nouragues inselberg seems quite different from that reported to occur in landscapes featured

281 by human activity and commonly studied in landscape ecology (Forman and Godron, 1981;

282 Harrison, 1991; Hanski, 1994), pointing on the importance of keystone structures, whatever 283 the scale at which they are distributed, in the determinism of soil arthropod assemblages 284 (Coulson et al., 2003; Tews et al., 2004). The heterogeneity observed at the inside of shrub thickets of the rock savanna, governed by cycles of destruction by fire and shrub renewal, is probably a decisive factor in the maintenance of a high level of biodiversity (Whittaker and Levin, 1977; Niemelä et al., 1996; Hansen, 2000).

\subsection{The impact of fire}

The main effect of vegetation types on soil arthropod communities was the contrast

292 between zones of destruction by fire and Clusia or Myrcia canopies (Factor 1 of PCA, Figs. 2-

293 4). Most arthropods present in the organic matter accumulated in zones destroyed by fire were microarthropods $(<0.4 \mathrm{~mm})$, mostly mites and springtails (Fig. 2). This size effect can be explained by the absence of litter, which forces fauna to live in a network of small 
297

conditions which select for organisms with a shorter duration of life (Bazzaz, 1983; Bongers, 1990; Prinzing et al., 2002). The depressive effect on macroarthropods of gaps opened by fire, windthrow or sylvicultural pratices has been registered (Huhta, 1976; Majer, 1984; Greenberg and Forrest, 2003), although to the exception of the very short term (Siira-Pietikäinen et al., 2003), as well as its counterpart, i.e. the development of a rich and diversified macroarthropod population during the establishment and growth of woody vegetation (Shure and Ragsdale, 1977; Hutson, 1980; Scheu and Schulz, 1996). The role of litter in the maintenance of macroarthropod populations has been verified experimentally (Pearse, 1943; David et al., 1991).

From the examination of animal guts, it appeared that the number of arthropods feeding on bacteria dominated in zones of destruction, opposed to those feeding on plant material under Clusia and Myrcia canopies (Fig. 3). This indicated opposing trends between foodwebs based on short-lived bacterial communities, associated with a high level of disturbance (zones of destruction), and those based on plant litter and fungal decomposition, associated with more stable environments (Clusia and Myrcia canopies), following the scheme developed by Hedlund et al. (2004). In that sense, arthropod communities living in zones of destruction resembled those living in cyanobacterial crusts, associated with pioneer stages of vegetation and soil development (Vaçulik et al., 2004), pointing on a temporary return to early stages of plant succession after fire events.

\subsection{The impact of Clusia and Myrcia canopies}

Although secondary in importance, differences between Clusia and Myrcia canopies were clearly expressed in the composition of arthropod communities (Fig. 2). The increase in 
322 the size of arthropods under Myrcia canopies, already seen in a previous study done on shrub 323 thickets of varying plant composition (Kounda-Kiki et al., 2004), could be attributed to the 324 increased accumulation of litter under Myrtaceae (Kounda-Kiki et al., 2006), known for their 325 litter recalcitrance due to a high terpenic content (Haagen-Smit, 1953). More morphospecies, 326 although at a lower level of arthropod density, were living under Clusia than under Myrcia 327 canopies (Table 1), as shown in a previous study (Kounda-Kiki et al., 2004). This could be 328 due to an earthworm effect under Clusia (Kounda-Kiki et al., 2006): litter is buried more 329 efficiently, then spread in underlying horizons, thus offering a variety of niches with a limited 330 amount of resources in each to the other invertebrates (Szlavecz, 1985; Marinissen and Bok, 331 1988; Hamilton and Sillman, 1989).

\section{Acknowledgements}

The authors are indebted to the staff of the Nouragues research station (CNRS-

Guyane) for accomodation and facilities during field session. Financial support was given by the Institut Fédératif de Recherche IFR 101, directed by R. Barbault, who is gratefully 338 acknowledged.

\section{References}

Baguette, M., Gérard, S., 1993. Effects of spruce plantations on carabid beetles in southern Belgium. Pedobiologia 37, 129-140. in the vegetation. Entomologist's Monthly Magazine 109, 79-84. 
348 Bazzaz, F.A., 1983. Characteristics of populations in relation to disturbance in natural and man-modified ecosystems. In: Mooney, H.A., Godron, M. (Eds.), Disturbance and ecosystems: components of response. Springer, Berlin, pp. 259-275.

Bengtsson, J., 2002. Disturbance and resilience in soil animal communities. European Journal of Soil Biology 38, 119-125.

Bongers, T., 1990. The maturity index: an ecological measure of environmental disturbance based on nematode species composition. Oecologia 83, 14-19.

Bremer, H., Sander, H., 2000. Inselbergs: geomorphology and geoecology. In: Porembski, S., Barthlott, W. (Eds.), Inselbergs: biotic diversity of isolated rock outcrops in tropical and temperate regions. Springer, Berlin, Germany, pp. 7-35.

Büdel, B., Weber, H.M., Porembski, S., Barthlott, W., 2002. Cyanobacteria of inselbergs in the Atlantic rainforest zone of eastern Brazil. Phycologia 41, 498-506.

Cannavacciuolo, M., Bellido, A., Cluzeau, D., Gascuel, C., Trehen, P., 1998. A geostatistical approach to the study of earthworm distribution in grassland. Applied Soil Ecology 9, 345-349.

Chagnon, M., Hébert, C., Paré, D., 2000. Community structures of Collembola in sugar maple forests : relations to humus type and seasonal trends. Pedobiologia 44, 148-174. 
372 Chust, G., Pretus, J.L., Ducrot, D., Bedòs, A., Deharveng, L., 2003. Identification of landscape units from an insect perspective. Ecography 26, 257-268.

374

Colwell, R.K., Coddington, J.A., 1994. Estimating terrestrial biodiversity through extrapolation. Philosophical Transactions of the Royal Society of London, Series B, Biological Sciences 345, 101-118.

Coulson, S.J., Hodkinson, I.D., Webb, N.R., 2003. Microscale distribution patterns in high Arctic soil microarthropod communities: the influence of plant species within the vegetation mosaic. Ecography 26, 801-809.

David, J.F., Devernay, S., Loucougaray, G., Le Floc'h, E., 1999. Belowground biodiversity in a Mediterranean landscape: relationships between saprophagous macroarthropod communities and vegetation structure. Biodiversity and Conservation 8, 753-767.

David, J.F., Ponge, J.F., Arpin, P., Vannier, G., 1991. Reactions of the macrofauna of a forest mull to experimental perturbations of litter supply. Oikos 61, 316-326.

Decaëns, T., Dutoit, T., Alard, D., Lavelle, P., 1998. Factors influencing soil macrofaunal communities in post-pastoral successions of western France. Applied Soil Ecology 9,

De Vries, H.K., Den Boer, P.J., 1990. Survival or populations of Agonum ericeti Panz. (Col., Carabidae) in relation to fragmentation of habitats. Netherlands Journal of Zoology 40, 484-498. 
398 De Wit, R., Bouvier, T., 2006. 'Everything is everywhere, but, the environment selects'; what did Baas Becking and Beijerinck really say? Environmental Microbiology 8, 755-758.

400

401 402

403

404

405

406

407

408

409

410

411

412

413

414

415

416

417

418

419

420

421

Drake, J.A., 1990. Communities as assembled structures: do rules govern pattern? Trends in Ecology and Evolution 5, 159-164.

Evans, W.G., 1983. Habitat selection in the Carabidae. Coleopterists Bulletin 37, 164-167.

Fahrig, L., 2003. Effects of habitat fragmentation on biodiversity. Annual Review of Ecology, Evolution and Systematics 34, 487-515.

Fairhurst, C.P., 1969. Activity and wandering in Tachypodoiulus niger (Leach) and Schizophyllum sabulosum (L.). Bulletin du Muséum National d'Histoire Naturelle 41 (Suppl. 2), 61-66.

Forman, R.T.T., Godron, M., 1981. Patches and structural components for a landscape ecology. BioScience 31, 733-740.

Garay, I., Hafidi, N., 1990. Study of a mixed forest litter of hornbeam (Carpinus betulus L.) and oak (Quercus sessiliflora Smith). III. Organization of the edaphic macroarthropod community as a function of litter quantity. Acta Oecologica 11, 43-60.

Gill, R.W., 1969. Soil microarthropod abundance following old-field litter manipulation. Ecology 50, 805-816. 
423 Greenberg, C.H., Forrest, T.G., 2003. Seasonal abundance of ground-occurring macroarthropods in forest and canopy gaps in the southern Appalachians. The Southern Naturalist 2, 591-608.

Haagen-Smit, A.J., 1953. The biogenesis of terpenes. Annual Review of Plant Physiology 4, 305-324.

Hamilton, W.E., Sillman, D.Y., 1989. Influence of earthworm middens on the distribution of soil microarthropods. Biology and Fertility of Soils 8, 279-284.

Hansen, R.A., 2000. Effects of habitat complexity and composition on a diverse litter microarthropod assemblage. Ecology 81, 1120-1132.

Hanski, I., 1994. Patch-occupancy dynamics in fragmented landscapes. Trends in Ecology and Evolution 9, 131-135.

Harrison, S., 1991. Local extinction in a metapopulation context: an empirical evaluation. Biological Journal of the Linnean Society 42, 73-88.

442 Hedlund, K., Griffiths, B., Christensen, S., Scheu, S., Setälä, H., Tscharntke, T., Verhoef, H., 2004. Trophic interactions in changing landscapes: responses of soil food webs. Basic and Applied Ecology 5, 495-503. 
446 Hopkins, P.J., Webb, N.R., 1984. The composition of the beetle and spider faunas on fragmented heathlands. Journal of Applied Ecology 21, 935-946.

Huhta, V., 1976. Effect of clear-cutting on numbers, biomass and community respiration of soil invertebrates. Annales Zoologici Fennici 13, 63-80.

Huhta, V., 1996. Community of Mesostigmata (Acari) in experimental habitat patches of forest floor. European Journal of Soil Biology 32, 99-105.

Hutson, B.R., 1980. The influence on soil development of the invertebrate fauna colonizing industrial reclamation sites. Journal of Applied Ecology 17, 277-286.

Ibisch, P.L., Rauer, G., Rudolph, D., Barthlott, W., 1995. Floristic, biogeographical, and vegetational aspects of Pre-cambrian rock outcrops (inselbergs) in eastern Bolivia. Flora 190, 299-314.

Joosse, E.N.G., 1981. Ecological strategies and population regulation of Collembola in heterogeneous environments. Pedobiologia 21, 346-356.

464

465 Kounda-Kiki, C., Ponge, J.F., Mora, P., Sarthou, C., 2008. Humus profiles and successional development in a rock savanna: a micromorphological approach pointing to fire as a disturbance event (Nouragues inselberg, French Guiana). Pedobiologia (in press). 
469 Kounda-Kiki, C., Vaçulik, A., Ponge, J.F., Sarthou, C., 2004. Soil arthropods in a developmental succession on the Nouragues inselberg (French Guiana). Biology and Fertility of Soils 40, 119-127.

Kounda-Kiki, C., Vaçulik, A., Ponge, J.F., Sarthou, C., 2006. Humus profiles under main vegetation types in a 'rock savanna' (Nouragues inselberg, French Guiana). Geoderma $136,819-829$.

Legendre, P., Legendre, L., 1998. Numerical Ecology, $2^{\text {nd }}$ ed. Elsevier, Amsterdam.

Loranger, G., Bandyopadhyaya, I., Razaka, B., Ponge, J.F., 2001. Does soil acidity explain altitudinal sequences in collembolan communities? Soil Biology and Biochemistry 33, 381-393.

Loranger-Merciris, G., Imbert, D., Bernhard-Reversat, F., Ponge, J.F., Lavelle, P., 2007. Soil fauna abundance and diversity in a secondary semi-evergreen forest in Guadeloupe (Lesser Antilles): influence of soil type and dominant tree species. Biology and Fertility of Soils 44, 269-276.

Majer, J.D., 1984. Short-term responses of soil and litter invertebrates to a cool autumn burn in jarrah (Eucalyptus marginata) forest in Western Australia. Pedobiologia 26, 229247.

Marinissen, J.C.Y., Bok, J., 1988. Earthworm-amended soil structure: its influence on Collembola populations in grassland. Pedobiologia 32, 243-252. 
495 Matlack, G.R., Leu, N.A., 2007. Persistence of dispersal-limited species in structured dynamic landscapes. Ecosystems 10, 1287-1298.

497

498 Niemelä, J., Haila, Y., Punttila, P., 1996. The importance of small-scale heterogeneity in 499 boreal forests: variation in diversity in florest-floor invertebrates across the succession

501

Ojala, R., Huhta, V., 2001. Dispsersal of microarthropods in forest soil. Pedobiologia 45, 443503 450.

504

505

Oliver, I. Beattie, A.J., 1996. Designing a cost-effective invertebrate survey: a test of methods 506 for rapid assessment of biodiversity. Ecological Applications 6, 594-607.

507

508

Paquin, P., Coderre, D., 1997. Changes in soil macroarthropod communities in relation to forest maturation through three successional stages in the Canadian boreal forest. Oecologia 112, 104-111.

Parr, T.W., 1978. An analysis of soil micro-arthropod succession. Science Proceedings of the Royal Dublin Society, Series A 6, 185-196.

Pearse, A.S., 1943. Effects of burning-over and raking-off litter on certain soil animal in the Duke Forest. The American Midland Naturalist 29, 406-424. 
518 Ponge, J.F., Dubs, F., Gillet, S., Sousa, J.P., Lavelle, P., 2006. Decreased biodiversity in soil springtail communities: the importance of dispersal and landuses history in heterogeneous landscapes. Soil Biology and Biochemistry 38, 1158-1161.

Porembski, S., Becker, U., Seine, R., 2000. Islands on islands: habitats on inselbergs. In: Porembski, S., Barthlott, W. (Eds.), Inselbergs: biotic diversity of isolated rock outcrops in tropical and temperate regions. Springer, Berlin, Germany, pp. 49-67.

Prinzing, A., Kretzler, S., Badejo, A., Beck, L., 2002. Traits of oribatid mite species that tolerate habitat disturbance due to pesticide application. Soil Biology and Biochemistry 34, 1655-1661.

Rantalainen, M.L., Haimi, J., Setälä, H., 2004. Testing the usefulness of habitat corridors in mitigating the negative effects of fragmentation: the soil fauna community as a model system. Applied Soil Ecology 25, 267-274.

Ricklefs, R.E., 1987. Community diversity: relative roles of local and regional processes. Science 235, 167-171. animal communities in two developmental phases of Norway spruce on an acidic substrate. Forest Ecology and Management 237, 47-56. 
541 Salmon, S., Ponge, J.F., 2001. Earthworm excreta attract soil srpingtails: laboratory experiments on Heteromurus nitidus (Collembola: Entomobryidae). Soil Biology and Biochemistry 33, 1959-1969.

Sarthou, C., 2001. Plant communities on a granitic outcrop. In: Bongers, F., CharlesDominique, P., Forget, P.M., Théry, M. (Eds.), Nouragues: Dynamics and OlantAnimal Interactions in a Neotropical Rainforest. Kluwer, Dordrecht, pp. 65-78.

Sarthou, C., Grimaldi, C., 1992. Mécanismes de colonisation par la végétation d'un inselberg granitique en Guyane Française. Revue d'Écologie (La Terre et la Vie) 47, 329-349.

Sarthou, C., Kounda-Kiki, C., Vaçulik, A., Mora, P., Ponge, J.F., 2009. Successional patterns on tropical inselbergs: a case study on the Nouragues inselberg (French Guiana). Flora (in press).

Sarthou, C., Thérézien, Y., Couté, A., 1995. Cyanophycées de l'inselberg des Nouragues. Nova Hedwigia 61, 85-109.

Sarthou, C., Villiers, J.F., 1998. Epilithic plant communities on inselbergs in French Guiana. Journal of Vegetation Science 9, 847-860.

Scheu, S., Schulz, E., 1996. Secondary succession, soil formation and development of a diverse community of oribatids and saprophagous soil macro-invertebrates. Biodiversity and Conservation 5, 235-250. 
566 Shure, D.J., Phillips, D.L., 1991. Patch size of forest openings and arthropod populations. Oecologia 86, 325-334.

Shure, D.J., Ragsdale, H.L., 1977. Patterns of primary succession on granite outcrop surfaces. Ecology 58, 993-1006.

Siira-Pietikäinen, A., Haimi, J., Siitonen, J., 2003. Short-term responses of soil macroarthropod community to clear felling and alternative forest regeneration methods. Forest Ecology and Management 172, 339-353.

Stanton, N.L., Tepedino, V.J., 1977. Island habitats in soil communities. Ecological Bulletins 25, 514-515.

Szlavecz, K., 1985. The effect of microhabitats on the leaf litter decomposition and on the distribution of soil animals. Horlarctic Ecology 8, 33-38.

Tews, J., Brose, U., Grimm, V., Tielbörger, K., Wichmann, M.C., Schwager, M., Jeltsch, F., 2004. Animal species diversity driven by habitat heterogeneity/diversity: the importance of keystone structures. Journal of Biogeography 31, 79-92.

Torgersen, C.E., Jones, J.A., Moldenke, A.R., Le Master, M.P., 1995. The spatial heterogeneity of soil invertebrates and edaphic properties in an old-growth forest stand in western Oregon. In: Collins, H.P., Robertson, G.P., Klug, M.J. (Eds.), The Significance and Regulation of Biodiversity. Kluwer, Dordrecht, pp. 225-236. 
591 Vaçulik, A., Kounda-Kiki, C., Sarthou, C., Ponge, J.F., 2004. Soil invertebrate activity in biological crusts on tropical inselbergs. European Journal of Soil Science 55, 539-549.

593

594 Van der Drift, J., 1962. The soil animals in an oak-wood with different types of humus formation. In: Murphy, P.W. (Ed.), Progress in Soil Zoology. Butterworths, London, pp. 343-347.

597

Vohland, K., Schroth, G., 1999. Distribution patterns of the litter macrofauna in agroforestry and monoculture plantations in central Amazonia as affected by plant species and management. Applied Soil Ecology 13, 57-68.

601

602 Wardle, D.A., Bardgett, R.D., Klironomos, J.N., Setälä, H., Van der Putten, W.H., Wall, 603 D.H., 2004. Ecological linkages between aboveground and belowground biota.

604 Science 304, 1629-1633.

605

606 Weigmann, G., 1982. The colonization of ruderal biotopes in the city of Berlin by arthropods.

607

608 In: Bornkamm, R., Lee, J.A., Seaward, M.R.D. (Eds.), Urban Ecology. Blackwell,

609

610 Whittaker, R.H., Levin, S.A., 1977. The role of mosaic phenomena in natural communities. Theoretical Population Biology 12, 117-139. 


\section{$613 \quad$ Figure captions}

614

615 Figure 1. Vegetation clumps on south-western slope of the Nouragues inselberg. 616 Bromeliacean carpets (Pitcairnia geyskesii) and shrub thickets (Clusia minor) are separated by naked granite more or less covered with a cyanobacterial biofilm.

619 Figure 2. Principal component analysis. Projection of additional variables in the plane of the first two components: taxonomic groups, size classes (Class $1=<0.4 \mathrm{~mm}$, Class $2=$ 0.4-1 mm, Class $3=>1 \mathrm{~mm}$ ) and number of arthropods per sample, counted as numbers of individuals (in italic type) or of morphospecies (in roman type), vegetation types and thickets $(\mathrm{A}, \mathrm{B}, \mathrm{C}) . \mathrm{Clu}=$ Clusia $; \mathrm{Myr}=$ Myrcia $; \mathrm{Zd}=$ zones of destruction by fire

625

626 Figure 3. Principal component analysis. Projection of additional variables in the plane of the first two components: gut content categories, vegetation types and thickets (A, B, C). $\mathrm{Clu}=$ Clusia $; \mathrm{Myr}=$ Myrcia $; \mathrm{Zd}=$ zones of destruction by fire 
Table 1. Numbers of morphospecies per vegetation type and mean numbers of individuals per square metre, distributed according to their occurrence in one, two or three vegetation types. $\mathrm{Zd}=$ Zones of destruction. $\mathrm{Clu}=$ Clusia. Myr $=$ Myrcia

\begin{tabular}{llll}
\hline & Zones of destruction & Clusia & Myrcia \\
\hline Morphospecies & & & \\
Zd & 22 & 0 & 0 \\
Clu & 0 & 44 & 0 \\
Myr & 0 & 0 & 30 \\
Zd+Clu & 17 & 17 & 0 \\
Zd+Myr & 14 & 0 & 14 \\
Clu+Myr & 0 & 28 & 28 \\
Zd+Clu+Myr & 48 & 48 & 48 \\
Total & 101 & $\mathbf{1 3 7}$ & $\mathbf{1 2 0}$ \\
& & & \\
Individuals & & & \\
Zd & 3989 & 0 & 0 \\
Clu & 0 & 5432 & 0 \\
Myr & 0 & 0 & 2546 \\
Zd+Clu & 5220 & 2165 & 0 \\
Zd+Myr & 1485 & 0 & 1358 \\
Clu+Myr & 0 & 14770 & 11077 \\
Zd+Clu+Myr & 121297 & 66972 & 50632 \\
Total & $\mathbf{1 3 1 9 9 2}$ & $\mathbf{8 9 3 3 9}$ & $\mathbf{6 5 6 1 4}$ \\
\hline
\end{tabular}

631 
Table 2. Numbers of morphospecies per shrub thicket and mean numbers of individuals per square metre, distributed according to their occurrence in one, two or three shrub thickets $(A, B, C)$

\begin{tabular}{llll}
\hline & A & B & C \\
\hline Morphospecies & & & \\
A & 43 & 0 & 0 \\
B & 0 & 17 & 0 \\
C & 0 & 0 & 32 \\
A $+B$ & 20 & 20 & 0 \\
A + C & 21 & 0 & 21 \\
B+C & 0 & 7 & 7 \\
A+B+C & 65 & 65 & 65 \\
Total & $\mathbf{1 4 9}$ & $\mathbf{1 0 9}$ & $\mathbf{1 2 5}$
\end{tabular}

Individuals

\begin{tabular}{llll} 
A & 6791 & 0 & 0 \\
$B$ & 0 & 2801 & 0 \\
C & 0 & 0 & 3438 \\
$A+B$ & 3226 & 3141 & 0 \\
$A+C$ & 4117 & 0 & 3395 \\
$B+C$ & 0 & 976 & 1188 \\
$A+B+C$ & 80766 & 102453 & 78219 \\
Total & $\mathbf{9 4 8 9 9}$ & $\mathbf{1 0 9 3 7 1}$ & $\mathbf{8 6 2 4 1}$ \\
\hline
\end{tabular}

633 


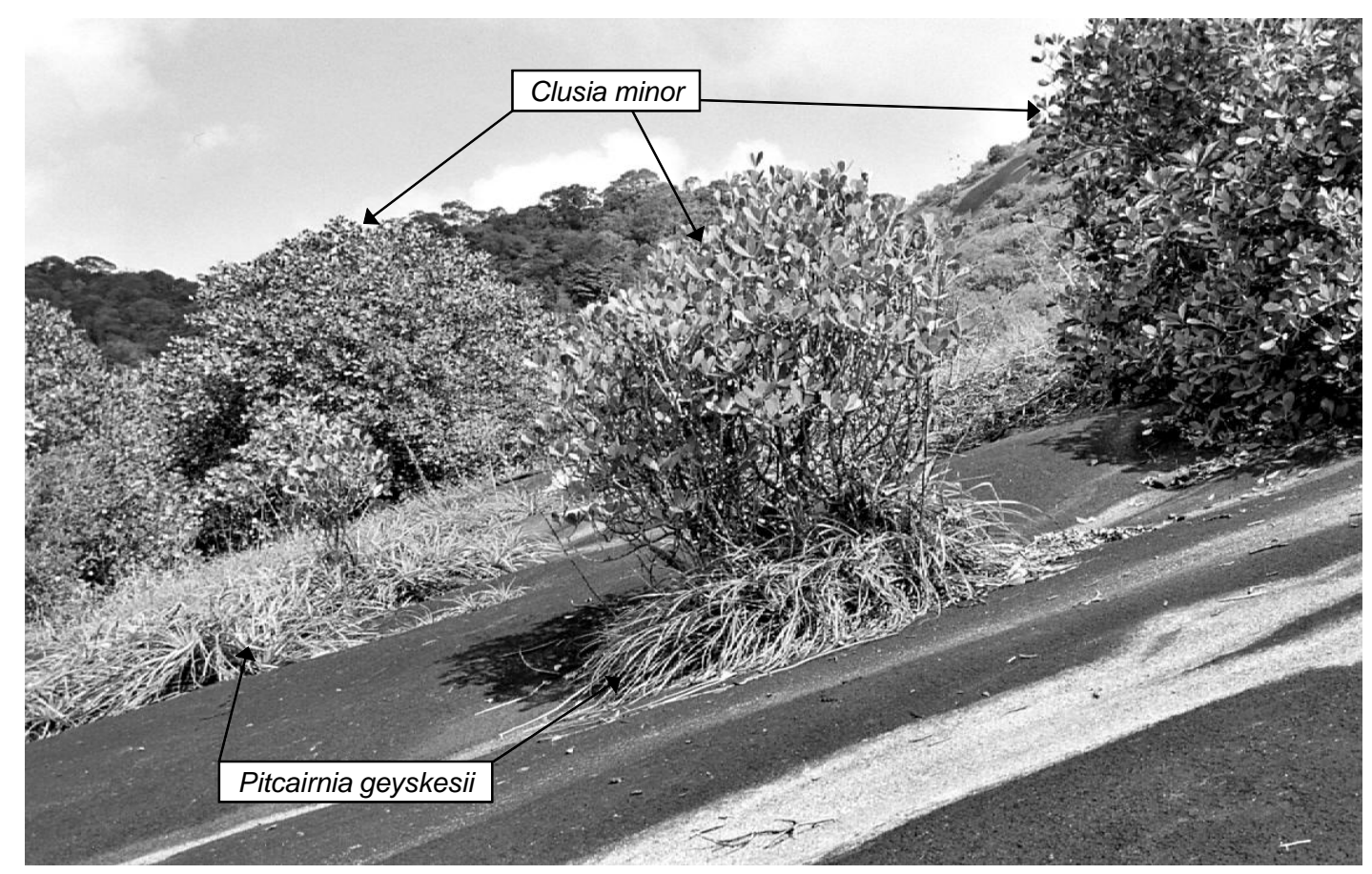

634

635 Fig. 1

636 


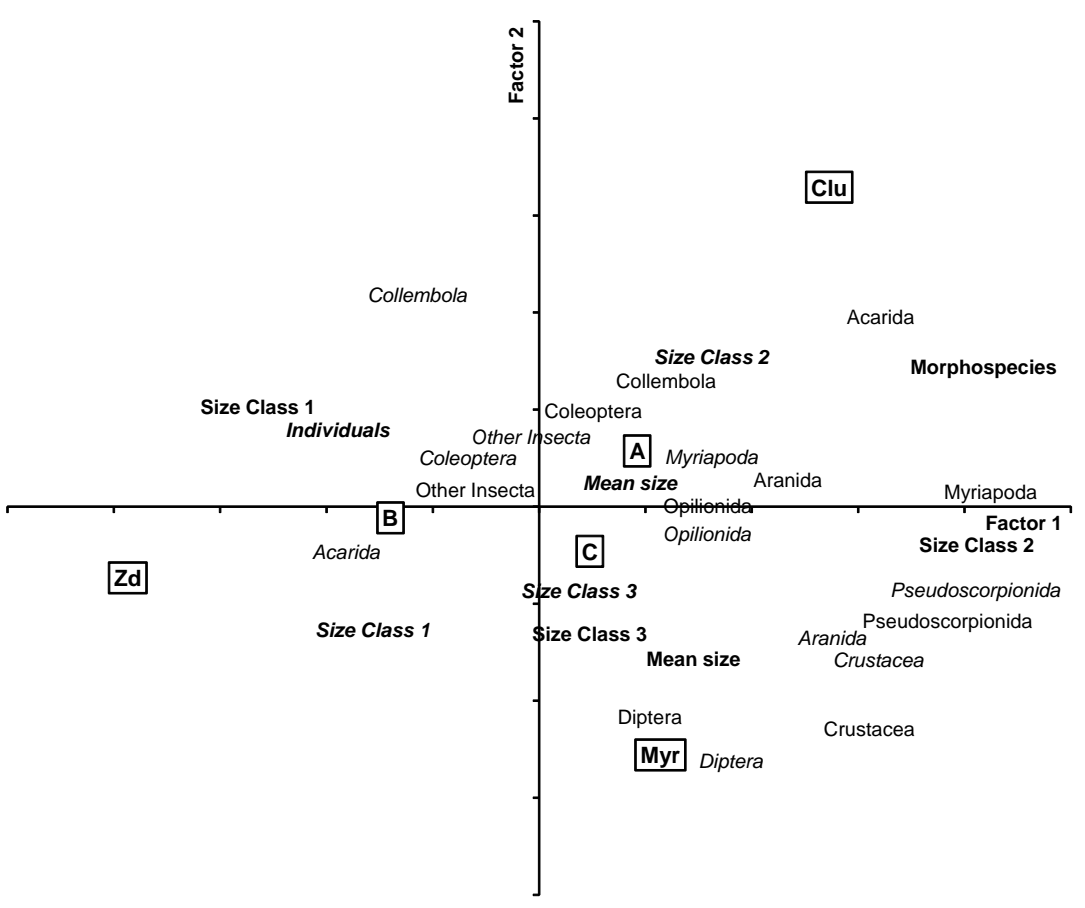

638 Fig. 2 


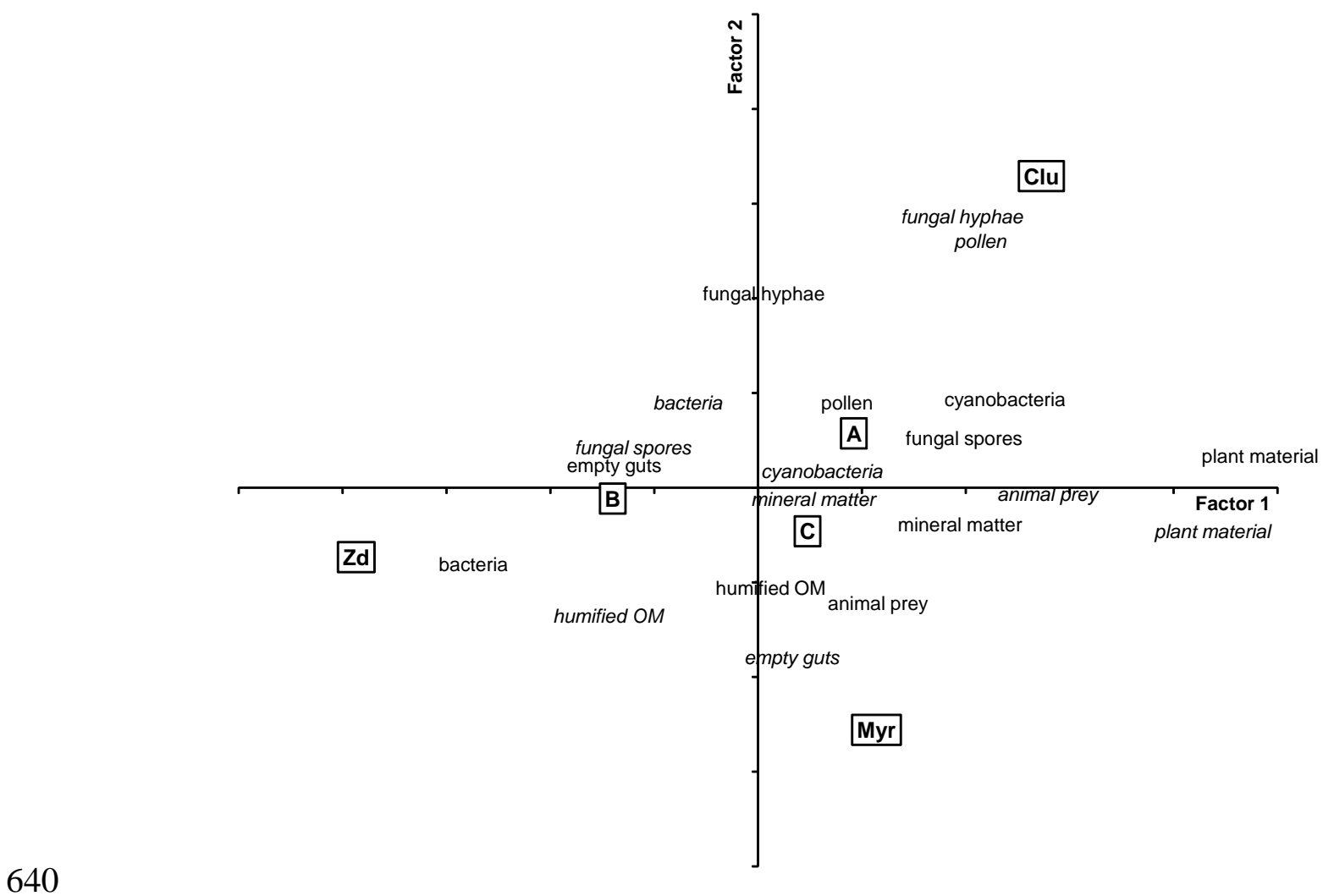

